\title{
Thoughts at a White Coat Ceremony
}

\author{
Robert T. Means, Jr.*
}

Departments of Internal Medicine (Hematology), Medical Education, and Pathology James H. Quillen College of Medicine, East Tennessee State University, Johnson City, Tennessee, USA

${ }^{*}$ Corresponding author: Robert T. Means, Jr, MD, MACP, Departments of Internal Medicine (Hematology), Medical Education, and Pathology, James H. Quillen College of Medicine, East Tennessee State University, Room 109, Building 2/Charles Ed Allen Hall, P.O. Box 70622, Johnson City TN 37614 USA; Phone: $4234396499 ;$ Fax: 423439 6470; Email: meansr@etsu.edu

Received: October 03, 2019; Accepted: October 14, 2019; Published: October 14, 2019

The first documented White Coat Ceremony was held 10 years after I entered medical school. Dr. Arnold P. Gold held his first White Coat Ceremony four years after that [1]. White Coat Ceremonies have spread throughout US medical schools and even internationally [2,3], largely through the support of the foundation established by Dr. Gold, his family and his colleagues [3]. I confess that when I first heard of these events sometime in the mid to late 1990s, the idea of presenting a white coat to entering medical students in a ceremony so that they would understand that they are beginning their entry into a profession, reminded me of an old Monty Python sketch. A middleaged man with spectacles (not unlike me) goes into an employment office and asks if there are any job openings for a lion tamer. When asked about his qualifications, he pulls out a pith helmet and says, "I've got the hat".

After I began attending White Coat Ceremonies in 2011, I realized my flippant initial reaction was unjust. I have come to appreciate White Coat Ceremonies as an opportunity for helping new students understand and embrace the values of the medical profession, with the white coat as a symbol of those values. Of course, the holistic admissions practices of most medical schools, at least in the US, aim to ensure that matriculated students possess many of the underlying humanistic qualities desired in physicians; and certainly, the students should understand that ultimately what makes one a physician is not the white coat but the person who is inside it.

However, even the apparently innocuous activity of the White Coat Ceremony has generated controversy. There was always some debate about the timing of the ceremony in the process of education: some schools would hold their ceremony at matriculation, while others might schedule it at the point in the curriculum where students shift from their preclinical studies to working in the clinics and wards. As earlier clinical exposure becomes more common, it is likely that White Coat Ceremonies held in the end of the second year of medical school will shift earlier in the educational process. More significant controversies revolve around the purpose and symbolism of the White Coat Ceremony itself.

For Dr. Arnold Gold, it seems clear that there was no intrinsic conflict between "humanism" and medical "professionalism" and the White Coat Ceremony represented both [3]. This perspective was certainly that held by physicians of his generation [4], and certainly is an aspirational goal even now. Even early in their history, White Coat Ceremonies were recognized as a tool for inculcating and teaching professionalism [5]. More recent commentators have argued that humanism, defined by values that are egalitarian and universal, has become distinct from professionalism, which may be parochial and culturally determined, and to at least some degree, self-interested [6]. It has also been suggested that the White Coat Ceremony is a defensive action by the medical profession, symbolizing a claim of entitlement in a world where physician leadership of healthcare is challenged [7]. Perhaps reflecting these perceived conflicts is a model in which a "profession-entry" ceremony is held early in the first year followed by a later "humanistic" ceremony including individual statements of values, a high level of student engagement, and artistic performances [2]. Most White Coat Ceremonies include recitation of some sort of commitment or oath: the meaning and appropriateness of such recitations has also been debated $[8,9]$.

The widely discussed issue of physician burnout engages the issues reflected in debates about the appropriateness and meaning of White Coat Ceremonies. Challenges to the autonomy of the medical profession are not only of a financial or administrative nature, but also reflect challenges to the humanistic expectations of patient centeredness and empathy. For that reason, it has been suggested that the term "burnout" should be replaced by the term "moral injury" [10].

When I discuss these issues with students, either individually or in small group learning settings, I emphasize that medicine is one of the professions as traditionally defined. More specifically, it is one of the three characterized as "learned professions". Medicine is also a vocation, or if one prefers, a "calling". The word "vocation" derives from the same Latin root as "vocal". It refers to something to which one is called or summoned, and accepting the call implies a commitment with attendant obligations. For medicine, the commitment is to the service of the patient. For each of us, the obligation is for that service always to reflect our best, with a further obligation that through lifelong learning we will strive to ensure that the gap between our best and the ever-shifting target of "THE best" is always small as circumstances permit. The White Coat Ceremony and the acceptance by a student of her or his first white coat symbolize recognition that they are beginning the path to that commitment and to the obligations that follow from it.

In thinking about these issues, I am reminded of things other than Monty Python. When I was in college, the US Navy ran a series of 
recruiting commercials with the tagline "It's not a job, it's an adventure". Medicine is not just a job: it is a profession, a calling, a commitment. However, a lot of us believe it is also an adventure [11].

Adapted from remarks made at the James H. Quillen College of Medicine Class of 2022 White Coat Ceremony - July 20, 2018. Dr. Means is a former dean of the College

The White Coat Ceremony was supported in part by the Arnold P. Gold Foundation.

\section{References}

1. Gold A, Gold S (2006) Humanism in medicine from the perspective of the Arnold Gold Foundation: challenges to maintaining the care in health care. Journal of child neurology 21: 546-549.

2. Tamai R, Koyawala N, Dietrick B, Pain D, Shochet R (2019) Cloaking as a community: re-imagining the White Coat Ceremony with a medical school learning community. J Med Educ Curric Dev 6: 2382120519830375.

3. Kavan MG (2009) The White Coat Ceremony: a tribute to the humanism of Arnold P. Gold. Journal of child neurology 24: 1051-1052.

4. Lepore MJ (1982) Death of the Clinician: Requiem Or Reveille? Springfield, IL USA: Charles C. Thomas; 1982.

5. Swick HM, Szenas P, Danoff D, Whitcomb ME (1999) Teaching professionalism in undergraduate medical education. Jama 282: 830-832.

6. Goldberg JL (2008) Humanism or professionalism? The White Coat Ceremony and medical education. Academic Medicine: Journal of the Association of American Medical Colleges 83: 715-722.

7. Russell PC (2002) The White Coat Ceremony: turning trust into entitlement. Teaching and learning in medicine 14: 56-59.

8. Huber SJ (2003) The White Coat Ceremony: a contemporary medical ritual. Journal of medical ethics. 29: 364-366.

9. Veatch RM (2002) White coat ceremonies: a second opinion. Journal of medical ethics. 28: 5-9.

10. Heston TF (2019) Pahang JA. Moral Injury or Burnout? South Med J 112: 483.

11. Robinson GC (1957) Adventures in Medical Education. A Personal Narrative of the Great Advance of American Medicine. Cambridge: Commonwealth Fund 1957. 